\title{
Fish Composition at Three Different Sites in Relation to Physico-chemical Characteristic of Yamuna River, India
}

\author{
Sumit Kumar* and Amita Saxena \\ College of Fisheries, G.B.Pant University of Agriculture and Technology, \\ Pantnagar, Udham Singh Nagar, Uttarakhand, India \\ *Corresponding author
}

\begin{abstract}
A B S T R A C T
Keywords

Yamuna, Fish,

Biodiversity,

Physico-chemical,

Delhi, Mathura,

Agra

Article Info

Accepted:

12 December 2020

Available Online:

10 January 2021

The present investigation was carried out to know the fish composition of Yamuna river at Delhi (B1), Mathura (B2) and Agra (B3). Monthly sampling from all the sampling sites was made for a period of 12 months (March 2019 - February 2020).A total of 45 fish species belonging to 8 orders and 16 families were recorded from three sampling sites during the study period in the Yamuna river. Mathura has highest number of fish diversity with 38 species and Delhi has recorded lowest fish biodiversity of 36 species. Order Cypriniformes has maximum number of species but family wise Siluriformes has recorded total of 7 family which indicates the dominance of cat fishes in Yamuna river. Physico-chemical parameters were found good for fishes in all sites except in Delhi where DO was on the lower side during some months. Diversion of water, discharge of domestic sewage and agricultural runoff were prominent among the disturbances that alter the habitat quality.
\end{abstract}

\section{Introduction}

River is simply defined as a dynamic body of water, which flows from higher ground elevation, like hills and mountains, towards lower levels, like the sea. Rivers are the most important fresh water resources used for domestic and irrigation purposes. The Yamuna River is one of north India's most polluted rivers, home to a rich diversity of flora and fauna and is the most significant water source. In Hindu mythology, it is considered as one of the most sacred rivers after the Ganges, and is one of the major tributaries of the river Ganges. Total length of the Yamuna up to its point of confluence with the Ganges is around $1370 \mathrm{~km}$.

Water resources need special interest for conservation, development and management for best and sustainable utilization. Given the increasing pressure on aquatic systems, documenting the available richness and establishing accurate estimates of the magnitude of biodiversity loss resulting from common human disturbances, such as landuse change and habitat loss, species invasions, and climate change is of particular importance 
(Murphy and Romanuk, 2014).Although river water makes up only about $0.2 \%$ of all the fresh water on earth, river play a very important role as vital carriers of water and nutrients to areas all around the earth.

In natural process, water pollution is mainly caused by the decomposition of vegetables, animals and weather products. Modifications in the water and habitat quality are mostly due to the forest removal, urbanization, embankments and diversions for irrigation and hydroelectric power stations May J.T. \& Brown. L.R., (2002).In Anthropogenic process, water pollution is caused by industrial, agricultural, domestic, radioactive, mining sources, use of fertilizer \& pesticides by human beings. In recent years, the growth of industry, technology, population and water use has increased the stress upon our water bodies. Municipal and industrial wastes, herbicides, pesticides and chemical fertilizers have entered the water bodies and degraded the water quality.

In general, most of the rivers in the country are facing similar situation, as a result there is sharp alterations in the physico-chemical parameters of the rivers, aquatic biota and fisheries in the down stream.Physicochemical characteristics are important determinants reflecting the condition of freshwater fish assemblages. The river Yamuna is a critical example of habitat alterations due to massive anthropogenic activities.

The degree of pollution is generally assessed by studying physical and chemical characteristics of the water bodies Duran and Suicmez (2007).The targets of the present study were to archive the fish species in connection to physico-chemical qualities of water and propose proper management, protection and administration to river.

\section{Materials and Methods}

\section{Sampling sites}

The study was carried out for a period of twelve months from March 2019-February 2020. The basis for selection of sampling locations was the changeability within the river stretch considering the variations in the hydrological regimes, pollution and biodiversity characteristics. The 1000-kmlong Yamuna River originates in the Himalayan mountains as a main tributary of the Ganges (Ganga) River. After descending through the Himalaya, the river passes through the capital city of India, Delhi, meanders through Agra and joins the Ganges River at Allahabad. One site from Union territory Delhi (B1) and two sites from districts of U.P. viz: Mathura (B2) and Agra (B3)were selected from Yamuna river which are presented in Figure 1.

\section{Sampling and data analysis}

The fishes were collected from the Yamuna river with the help of local fishermen during the year March 2019 to February 2020. The fishes were preserved in $10 \%$ formaldehyde solution for taxonomic analysis. Fish identification was done using standard literature by Day (1951), Talwar and Jhingran (1991) and Jayaram (2010).

The water samples were collected monthly from all the sampling site for analysis of water quality parameters. Water temperature, dissolved oxygen, free $\mathrm{CO}_{2}, \mathrm{pH}$ and electrical conductivity were measured at the sampling site.

A standard mercury thermometer (Borosil) was used to measure the water temperature. The $\mathrm{pH}$ of the water samples was measured with the help of portable 'HANNA' digital $\mathrm{pH}$ meter. Electronic conductivity was 
measured by using a portable 'HANNA' digital conductivity meter. Dissolved oxygen and free $\mathrm{CO}_{2}$ were measured according to procedure prescribed by (APHA, 2012).Statistical consideration should be a central element in the sampling design and in drawing conclusions. An important step is to standardize sampling and evaluation methods Skjoldal et al., (2000).

\section{Results and Discussion}

The physico-chemical parameters affect aquatic environment and are supposed to be the limiting factors for the continued existence of aquatic life of flora and fauna (Chitmanat and Traichaiyaporn, 2010).

\section{Dissolved oxygen}

Dissolved oxygen $(\mathrm{mg} / \mathrm{l})$ in the Yamuna river at station $\mathrm{B} 1$ the minimum value was 2.1 in the month of June and maximum was observed 6.5 in month of January. The average value of 4.53 with $\mathrm{SD} \pm 1.58$ was observed at site B1. At station B2 the minimum value was 3.4 in the month of April and maximum was 7.4 in the month of January. The average value of 5.4 with $\mathrm{SD} \pm$ 1.38 was observed at station B2. At station B3 the minimum value was 3.8 in the month of April and maximum was 7.3 in the month of January.

The average value of 5.62 with $\mathrm{SD} \pm 1.26$ was observed at station B3 which are presented in Figure 6 and Table 3, 4\&5. Khanna, D.R. and Bhutiani, R., (2003) also observed similar kind of trend in river Ganga at Haridwar. Dissolved oxygen is important and, in many cases, serves as a major lacking factor for regulating aquatic life. Babita, S. and Rao, S.N., (2015) reported maximum values of dissolved oxygen as $10.5 \mathrm{mg} / \mathrm{l}$ in the month of January and minimum $8 \mathrm{mg} / \mathrm{l}$ in August in Kosi river, Almora during his investigation.

\section{Free carbon di-oxide}

The free $\mathrm{CO}_{2}(\mathrm{mg} / \mathrm{l})$ in Yamuna river at station $\mathrm{B} 1$ the minimum value was 4.8 in the month of February and maximum was 15.3 in the month of June. The average value of 9.58 with $\mathrm{SD} \pm 3.35$ was observed at site B1. At station B2 the minimum value was 5.5 in the month of December and maximum was 12.1 in the month of June. The average value of 8.32 with $\mathrm{SD} \pm 2.03$ was observed at station B2. At station B3 the minimum value was 4.8 in the month of January and maximum was 11.2 in the month of June. The average value of 7.95 with $\mathrm{SD} \pm 2.08$ was observed at station B3 which are presented in Figure 7 and Table $3,4 \& 5$. A similar result of free $\mathrm{CO}_{2}$ was reported by (Pramod Kumar et al., 2014) from Kali River in Pithoragarh, Uttarakhand. According to Badola and Singh (1981), the maximum values of free $\mathrm{CO}_{2}$ in rainy season in Alaknanda river was observed due to its utilization by negligible phytoplankton population and less availability of sunlight.

\section{Water temperature}

In the Yamuna river at station B1 the minimum value of water temperature $\left({ }^{\circ} \mathrm{C}\right)$ was 18.8 in the month of January and maximum was observed 32 in month of June. The average value of 24.67 with $\mathrm{SD} \pm 4.10$ was observed at site B1. At station B2 the minimum value was 20.3 in the month of January and maximum was 32.6 in the month of July. The average value of 26.67 with SD \pm 4.13 was observed at station B2. At station B3 the minimum value was 21.8 in the month of January and maximum was 32.8 in the month of May. The average value of 28.01 with SD \pm 3.40 was observed at station B3 which are presented in Figure 8 and Table 3, 4 \& 5. The maximum temperature in river at all sampling sites was observed during monsoon season which is generally due to suspended particles as they absorb and scatter sunlight in water 
column and lower in winter due to rarely rainfall \& cold. The trend of water temperature found upward from winter season to summer season followed by downward from monsoon season onwards. Similar trend of water temperature was observed by Khanna et al., (2012) in river Ganga at Haridwar.

\section{pH}

In the Yamuna river at station B1 the minimum value of $\mathrm{pH}$ was 7.3 in the month of July and maximum was observed 8.2 in month of January. The average value of 7.77 with $\mathrm{SD} \pm 0.28$ was observed at site B1. At station $\mathrm{B} 2$ the minimum value was 7.6 in the month of March and maximum was 8.3 in the month of December. The average value of 7.96 with $\mathrm{SD} \pm 0.21$ was observed at station B2. At station $\mathrm{B} 3$ the minimum value was 7.5 in the month of June and maximum was 8.3 in the month of January. The average value of 7.85 with $\mathrm{SD} \pm 0.23$ was observed at station B3 which are presented in Figure 9 and Table 3, 4 \& 5. Khanna et al., (2007) in their study on Ganga river found higher values of $\mathrm{pH}$ during monsoon season which might be due to increase chemical load in the river and minimum in winter season. Similar results were made by Gautam et al., (2015) in Subarnarekha River.

Table.1 Fish composition found in Yamuna river during the study period

\begin{tabular}{|c|c|c|}
\hline Order & Family & Species \\
\hline \multirow[t]{2}{*}{ Clupeiformes } & 1. Clupeidae & $\begin{array}{l}\text { 1. Gonialosamanmina(Hamilton, 1822) } \\
\text { 2. Gudusiachapra(Hamilton, 1822) }\end{array}$ \\
\hline & 2. Pristigasteridae & 1. Ilishamegaloptera(Swainson, 1839) \\
\hline \multirow[t]{2}{*}{ Cypriniformes } & 1. Cyprinidae & $\begin{array}{l}\text { 1. Cirrhinusreba(Hamilton, 1822) } \\
\text { 2. Cyprinus carpio(Linnaeus, 1758) } \\
\text { 3. Puntius sophore(Hamilton, 1822) } \\
\text { 4. Salmophasiabacaila(Hamilton, 1822) } \\
\text { 5. Amblypharyngodonmola(Hamilton, } \\
\text { 1822) } \\
\text { 6. Cabdiomorar(Hamilton, 1822) } \\
\text { 7. Devariodevario(Hamilton, 1822) } \\
\text { 8. Bariliusbarila(Hamilton, 1822) } \\
\text { 9. Bariliusbendelisis(Hamilton, 1807) } \\
\text { 10. Osteobramacotiacotia(Hamilton, 1822) } \\
\text { 11. Labeoangra(Hamilton, 1822) } \\
\text { 12. Rasbora daniconius(Hamilton, 1822) } \\
\text { 13. Catlacatla(Hamilton, 1822) } \\
\text { 14. Cirrhinusmrigala(Hamilton, 1822) } \\
\text { 15. Labeobata (Hamilton, 1822) } \\
\text { 16. Pethiaconchonius(Hamilton, 1822) }\end{array}$ \\
\hline & 2. Nemacheilidae & 1. Acanthocobitisbotia(Hamilton, 1822) \\
\hline Siluriformes & 1. Bagridae & $\begin{array}{ll}\text { 1. } & \text { Sperataseenghala(Hamilton, 1822) } \\
\text { 2. } & \text { Mystusvittatus(Bloch, 1794) } \\
\text { 3. } & \text { Mystustengra(Hamilton, 1822) } \\
\text { 4. } & \text { Mystuscavasius(Hamilton, 1822) } \\
\text { 5. } & \text { Sperataaor (Hamilton, 1822) }\end{array}$ \\
\hline
\end{tabular}




\begin{tabular}{|c|c|c|}
\hline & 2. Siluridae & $\begin{array}{l}\text { 1. Ompokbimaculatus(Bloch, 1794) } \\
\text { 2. Ompokpabda (Hamilton, 1822) }\end{array}$ \\
\hline & 3. Claridae & 1. Clariusgariepinus(Burchell, 1822) \\
\hline & 4. Sisoridae & $\begin{array}{l}\text { 1. Gagatacenia(Hamilton, 1822) } \\
\text { 2. Gogangraviridescens (Hamilton, 1822) }\end{array}$ \\
\hline & 5. Schilbeidae & $\begin{array}{l}\text { 1. Ailiacoila(Hamilton, 1822) } \\
\text { 2. } \text { Clupisomagarua (Hamilton, 1822) } \\
\text { 3. Eutropiichthysvacha (Hamilton, 1822) } \\
\text { 4. }\end{array}$ \\
\hline & 6. Heteropneustidae & 1. Heteropneustesfossilis(Bloch, 1794) \\
\hline & 7. Pangasiidae & 1. Pangasius pangasius(Hamilton, 1822) \\
\hline Mugiliformes & 1. Mugilidae & $\begin{array}{l}\text { 1. Rhinomugilcorsula(Hamilton, 1822) } \\
\text { 2. Sicamugilcascasia(Hamilton, 1822) }\end{array}$ \\
\hline Ophiocephaliformes & 1. Channidae & $\begin{array}{l}\text { 1. Channa punctatus(Bloch, 1793) } \\
\text { 2. Channastriata(Bloch, 1793) } \\
\text { 3. Channamarulius(Hamilton, 1822) }\end{array}$ \\
\hline Anabantiformes & 1. Osphronemidae & $\begin{array}{l}\text { 1. Tricchogasterfaciata(Bloch } \\
\& \text { Schneider, 1801) }\end{array}$ \\
\hline Perciformes & 1. Ambassidae & $\begin{array}{l}\text { 1. Chanda nama(Hamilton, 1822) } \\
\text { 2. Parambasisranga(Hamilton, 1822) }\end{array}$ \\
\hline Cichliformes & 1. Cichlidae & 1. Oreochromis niloticus(Linnaeus, 1758) \\
\hline
\end{tabular}

Table.2 Fish occurance at different sampling sites during the study period

\begin{tabular}{|c|l|l|l|l|}
\hline S.No. & Fish Species & \multicolumn{2}{l}{ B1 } & \multicolumn{2}{l|}{ B2 } \\
\hline Family & Clupeidae & + & + & + \\
\hline $\mathbf{1}$ & Gonialosamanmina (Hamilton, 1822) & - & + & + \\
\hline $\mathbf{2}$ & Gudusiachapra (Hamilton, 1822) & \multicolumn{2}{l|}{} \\
\hline Family & Cyprinidae & + & + & + \\
\hline $\mathbf{3}$ & Cirrhinusreba (Hamilton, 1822) & + & + & + \\
\hline $\mathbf{4}$ & Cyprinus carpio (Linnaeus, 1758) & + & + & + \\
\hline $\mathbf{5}$ & Puntius sophore (Hamilton, 1822) & + & + & + \\
\hline $\mathbf{6}$ & Salmophasiabacaila (Hamilton, 1822) & - & + & - \\
\hline $\mathbf{7}$ & Amblypharyngodonmola (Hamilton, 1822) & + & + & + \\
\hline $\mathbf{8}$ & Cabdiomorar (Hamilton, 1822) & + & - & - \\
\hline $\mathbf{9}$ & Devariodevario (Hamilton, 1822) & + & + & - \\
\hline $\mathbf{1 0}$ & Bariliusbarila (Hamilton, 1822) & + & - & + \\
\hline $\mathbf{1 1}$ & Bariliusbendelisis (Hamilton, 1807) & + & + & + \\
\hline $\mathbf{1 2}$ & Osteobramacotiacotia (Hamilton, 1822) & + & + & - \\
\hline $\mathbf{1 3}$ & Labeoangra (Hamilton, 1822) & + & - & + \\
\hline $\mathbf{1 4}$ & Rasbora daniconius (Hamilton, 1822) & + & - & + \\
\hline $\mathbf{1 5}$ & Catlacatla (Hamilton, 1822 & - & + & + \\
\hline $\mathbf{1 6}$ & Cirrhinusmrigala (Hamilton, 1822) & - & + & + \\
\hline $\mathbf{1 7}$ & Labeobata (Hamilton, 1822) & + & + & + \\
\hline
\end{tabular}




\begin{tabular}{|c|c|c|c|c|}
\hline 18 & Pethiaconchonius (Hamilton, 1822) & - & - & + \\
\hline \multicolumn{5}{|c|}{ Family- Nemacheilidae } \\
\hline 19 & Acanthocobitisbotia(Hamilton, 1822) & + & + & + \\
\hline \multicolumn{5}{|c|}{ Family - Bagridae } \\
\hline 20 & Sperataseenghala(Hamilton, 1822) & + & + & + \\
\hline 21 & Mystusvittatus(Bloch, 1794) & + & + & + \\
\hline 22 & Mystustengra(Hamilton, 1822) & + & + & + \\
\hline 23 & Mystuscavasius(Hamilton, 1822) & + & + & + \\
\hline 24 & Sperataaor (Hamilton, 1822) & + & + & + \\
\hline \multicolumn{5}{|c|}{ Family- Siluridae } \\
\hline 25 & Ompokbimaculatus(Bloch, 1794) & + & - & - \\
\hline 26 & Ompokpabda (Hamilton, 1822) & + & - & - \\
\hline \multicolumn{5}{|c|}{ Family- Mugilidae } \\
\hline 27 & Rhinomugilcorsula (Hamilton, 1822) & + & + & + \\
\hline 28 & Sicamugilcascasia (Hamilton, 1822) & + & + & + \\
\hline \multicolumn{5}{|c|}{ Family- Claridae } \\
\hline 29 & Clariusgariepinus (Burchell, 1822) & + & + & + \\
\hline \multicolumn{5}{|c|}{ Family- Sisoridae } \\
\hline 30 & Gagatacenia(Hamilton, 1822) & - & + & + \\
\hline 31 & Gogangraviridescens (Hamilton, 1822) & + & + & - \\
\hline \multicolumn{5}{|c|}{ Family- Schilbeidae } \\
\hline 32 & Ailiacoila(Hamilton, 1822) & + & + & + \\
\hline 33 & Clupisomagarua (Hamilton, 1822) & + & + & + \\
\hline 34 & Eutropiichthysvacha (Hamilton, 1822) & + & + & + \\
\hline 35 & Neotropiusatherinoides (Bloch, 1794) & - & + & + \\
\hline \multicolumn{5}{|c|}{ Family- Heteropneustidae } \\
\hline 36 & Heteropneustesfossilis(Bloch, 1794) & + & + & + \\
\hline \multicolumn{5}{|c|}{ Family- Pangasiidae } \\
\hline 37 & Pangasius pangasius (Hamilton, 1822) & + & + & + \\
\hline \multicolumn{5}{|c|}{ Family- Channidae } \\
\hline 38 & Channa punctatus (Bloch, 1793) & + & + & + \\
\hline 39 & Channastriata (Bloch, 1793) & + & + & + \\
\hline 40 & Channamarulius (Hamilton, 1822) & + & + & + \\
\hline \multicolumn{5}{|c|}{ Family- Osphronemidae } \\
\hline 41 & Tricchogasterfaciata (Bloch \&Schneider, 1801) & + & + & - \\
\hline \multicolumn{5}{|c|}{ Family- Ambassidae } \\
\hline 42 & Chanda nama(Hamilton, 1822) & + & + & + \\
\hline 43 & Parambasisranga(Hamilton, 1822) & + & + & + \\
\hline \multicolumn{5}{|c|}{ Family- Cichlidae } \\
\hline 44 & Oreochromis niloticus(Linnaeus, 1758) & + & + & + \\
\hline \multicolumn{5}{|c|}{ Family- Pristigasteridae } \\
\hline 45 & Ilishamegaloptera(Swainson, 1839) & - & + & + \\
\hline & Total & 36 & 38 & 37 \\
\hline
\end{tabular}


Table.3 Physico-chemical parameters observed at site-1

\begin{tabular}{|c|c|c|c|c|c|}
\hline Months & Do & CO$_{2}$ & Temperature & Ph & Conductivity \\
\hline March & 3.6 & 9.8 & 24.5 & 7.7 & 349 \\
\hline April & 2.8 & 12.4 & 26.5 & 7.6 & 368 \\
\hline May & 2.2 & 14.2 & 29 & 7.5 & 396 \\
\hline June & 2.1 & 15.3 & 32 & 7.4 & 425 \\
\hline July & 4.2 & 10.7 & 28 & 7.3 & 482 \\
\hline August & 4.4 & 11.2 & 26 & 7.9 & 512 \\
\hline September & 5.2 & 8.9 & 25.5 & 8 & 529 \\
\hline October & 5.4 & 8.8 & 24.6 & 7.8 & 456 \\
\hline November & 6.1 & 7.2 & 22.4 & 8 & 405 \\
\hline December & 6.3 & 6.3 & 19.6 & 8.1 & 341 \\
\hline January & 6.5 & 5.4 & 18.8 & 8.2 & 269 \\
\hline February & 5.6 & 4.8 & 19.1 & 7.8 & 308 \\
\hline Mean & 4.533333 & 9.583333 & 24.66667 & 7.775 & 403.3333 \\
\hline SD & 1.570948 & 3.354192 & 4.109265 & 0.283244 & 81.07722 \\
\hline
\end{tabular}

Table.4 Physico-chemical parameters observed at site-2

\begin{tabular}{|c|c|c|c|c|c|}
\hline Months & Do & $\mathbf{C O}_{\mathbf{2}}$ & Temperature & Ph & Conductivity \\
\hline March & 4.6 & 8.2 & 26.6 & 7.6 & 672 \\
\hline April & 3.4 & 10.1 & 28.2 & 7.8 & 702 \\
\hline May & 4.2 & 9.2 & 31.3 & 7.7 & 764 \\
\hline June & 3.8 & 12.1 & 31.5 & 7.9 & 789 \\
\hline July & 4.8 & 9.6 & 32.6 & 8.1 & 834 \\
\hline August & 5.2 & 9.1 & 28.4 & 7.9 & 902 \\
\hline September & 4.8 & 9.8 & 27.2 & 8.2 & 958 \\
\hline October & 5.9 & 7.9 & 26.8 & 7.9 & 934 \\
\hline November & 7.2 & 6.7 & 24.6 & 8.1 & 848 \\
\hline December & 7.4 & 5.5 & 21.2 & 8.3 & 714 \\
\hline January & 7.1 & 5.6 & 20.3 & 8.2 & 628 \\
\hline February & 6.4 & 6.1 & 21.4 & 7.9 & 656 \\
\hline Mean & 5.4 & 8.325 & 26.675 & 7.966667 & 783.4167 \\
\hline SD & 1.374442 & 2.039664 & 4.135462 & 0.214617 & 112.2517 \\
\hline
\end{tabular}


Table.5 Physico-chemical parameters observed at site-3

\begin{tabular}{|c|c|c|c|c|c|}
\hline Months & Do & $\mathbf{C O}_{\mathbf{2}}$ & Temperature & Ph & Conductivity \\
\hline March & 4.4 & 9.2 & 28.1 & 7.8 & 1136 \\
\hline April & 3.8 & 10.8 & 29.5 & 7.7 & 1168 \\
\hline May & 4.6 & 8.4 & 32.8 & 7.9 & 1198 \\
\hline June & 4.1 & 11.2 & 31.6 & 8.1 & 1206 \\
\hline July & 5 & 9.5 & 29 & 8 & 1238 \\
\hline August & 5.6 & 8.1 & 30.2 & 7.7 & 1285 \\
\hline September & 5.4 & 8.4 & 31 & 8.1 & 1326 \\
\hline October & 6.4 & 7.8 & 28 & 8 & 1284 \\
\hline November & 6.9 & 6.2 & 26.4 & 8.1 & 1137 \\
\hline December & 7.2 & 5.9 & 24 & 7.9 & 1065 \\
\hline January & 7.3 & 4.8 & 21.8 & 8.2 & 1098 \\
\hline February & 6.8 & 5.2 & 23.8 & 8.1 & 1128 \\
\hline Mean & 5.625 & 7.958333 & 28.01667 & 7.966667 & 1189.083 \\
\hline SD & 1.262843 & 2.085647 & 3.407701 & 0.166969 & 81.52686 \\
\hline
\end{tabular}

Fig.1 Sampling sites on Yamuna river

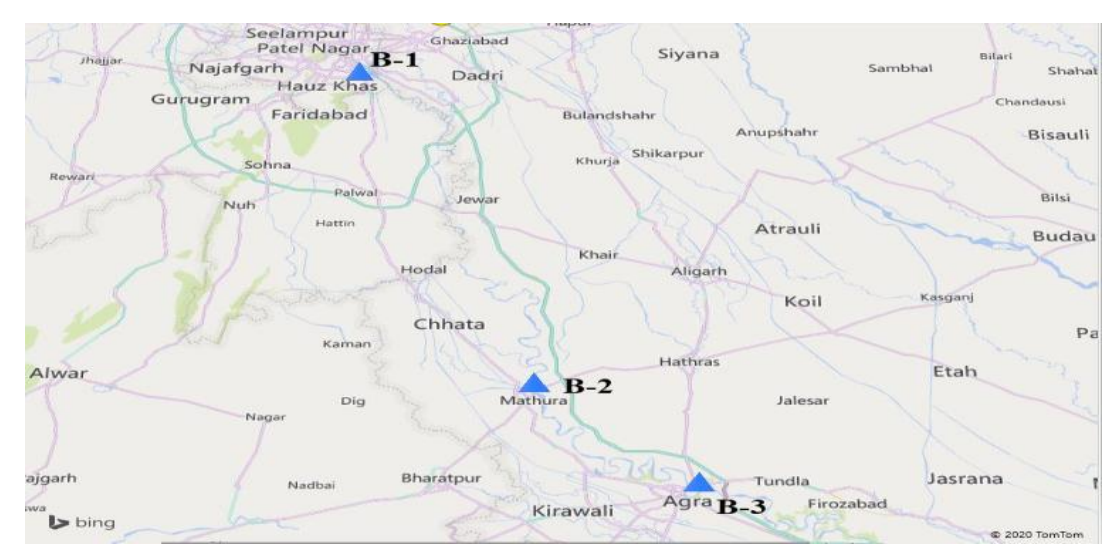

Fig.2 Fish composition in Yamuna river

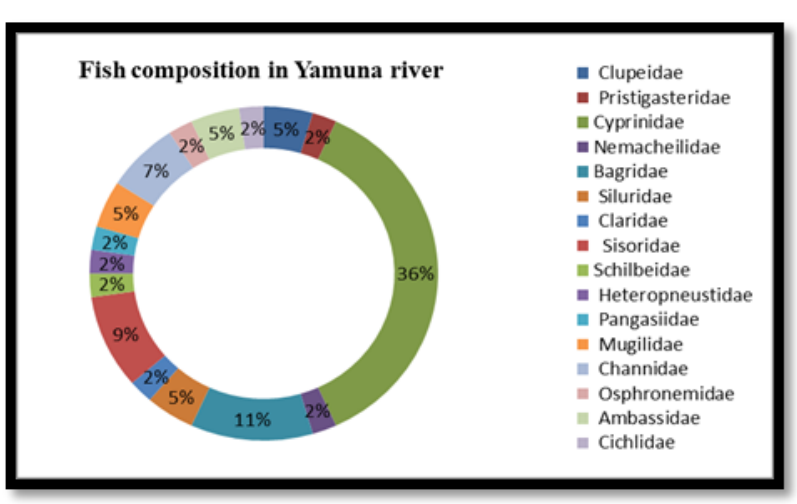


Fig.3 Fish composition at site B1

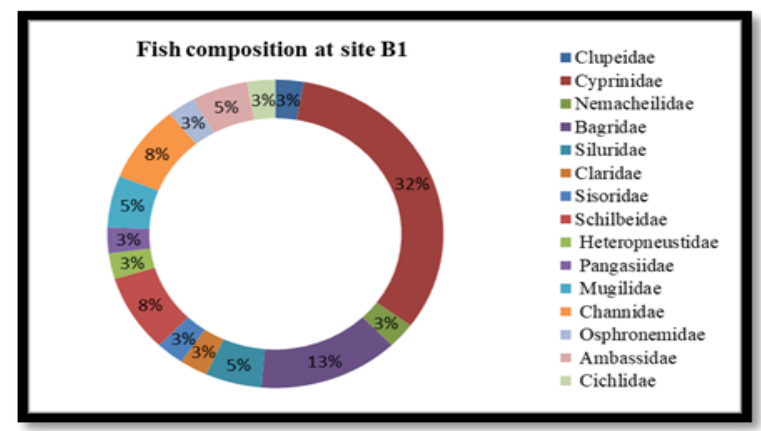

Fig.4 Fish composition at site B2

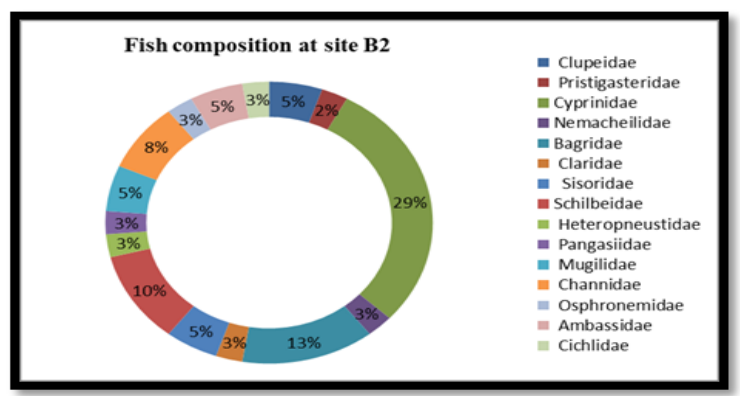

Fig.5 Fish composition at site B3

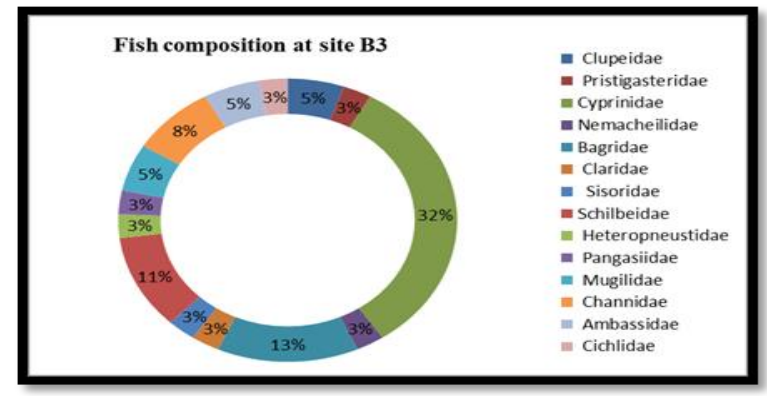

Fig.6 Monthly variation in Dissolved oxygen

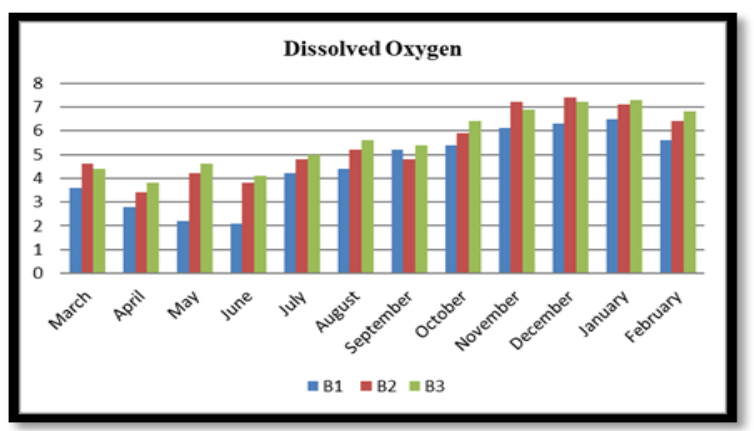


Fig.7 Monthly variation in Free Carbon di-oxide

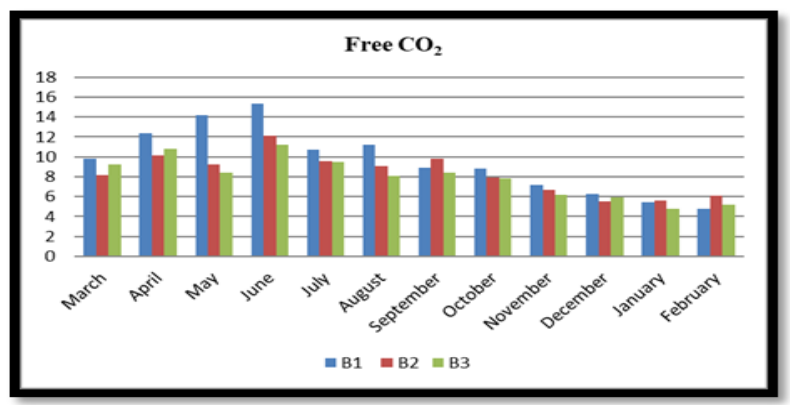

Fig.8 Monthly variation in Water temperature

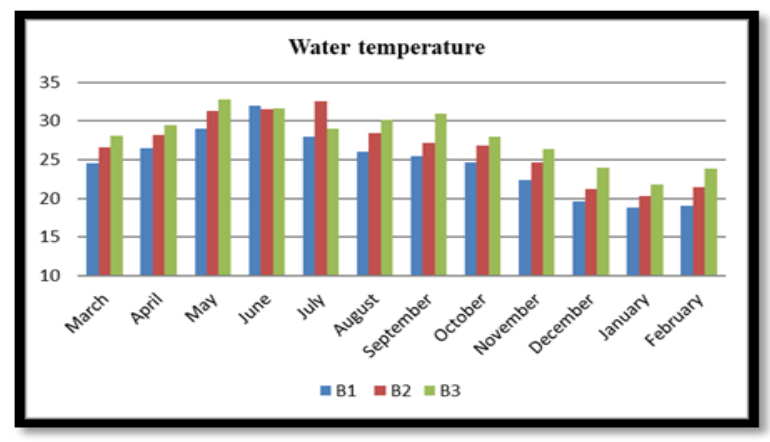

Fig.9 Monthly variation in $\mathrm{pH}$

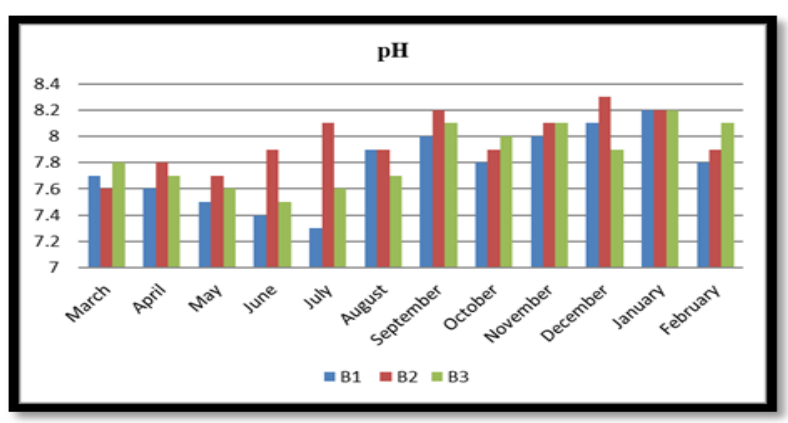

Fig.10 Monthly variation in Electrical conductivity

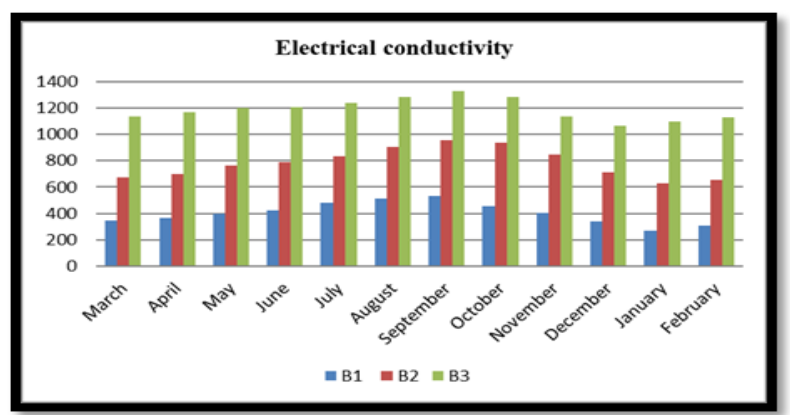




\section{Electrical conductivity}

The electrical conductivity $(\mu \mathrm{S} / \mathrm{cm})$ in Yamuna river at station B1 the minimum value was 269 in the month of January and maximum was 529 in the month of September. The average value of 403.33 with $\mathrm{SD} \pm 81.07$ was observed at site B1. At station $\mathrm{B} 2$ the minimum value was 628 in the month of January and maximum was 958 in the month of September. The average value of 783.41 with $\mathrm{SD} \pm 112.25$ was observed at station B2. At station B3 the minimum value was 1065 in the month of December and maximum was 1326 in the month of September. The average value of 1189.08 with $\mathrm{SD} \pm 81.52$ was observed at station $\mathrm{B} 3$ which are presented in Figure 10 and Table 3, 4 \& 5. Singh et al., (2006) and Khanna et al.,(2005) also noted similar trend of conductivity in river Ganga at Bulandshahar and river Panvdhoi at Saharanpur respectively. Higher values during monsoon season may be due to large number of salts, silts and greater ionic concentration inlet flow carried by river (Jha and Barat, 2003).

\section{Fish biodiversity of Yamuna river}

Overall 45 fish species belonging to 8 orders and 16 family were recorded from Yamuna river from all sites during the study period. Cyprinidae were the most predominant order (36\%) followed by Bagridae (11\%),Sisoridae (9\%), Channidae (7\%), Clupeidae, Siluridae, Muglidae and Ambassidaeeach with (5\%), Pristigasteridae, Nemacheilidae, Claridae, Schilbeidae, Heteropneustidae, Pangasiidae, Osphronemidae and Cichlidae with (2\%) each. At site B1a total of 36 fish species were recorded belonging to 8 order and 15 family. Cyprinidae were the most dominant with $(32 \%)$ followed by Bagridae (13\%), Schilbeidae and Channidae(8\%), Sisoridae, Muglidae and Ambassidae (5\%), Clupeidae, Nemacheilidae, Claridae, Sisoridae,
Heteropneustidae,

Pangasiidae, Osphronemidae, and Cichlidae (3\%). At site B2 a total of 38 species were recorded belonging to 8 order and 15 family. Cyprinidae were the most dominant with (29\%) followed by Bagridae (13\%), Schilbeidae (10\%), Channidae (8\%), Clupeidae, Sisoridae, Muglidae and Ambassidae (5\%), Nemacheilidae, Claridae, Heteropneustidae, Pangasiidae, Osphronemidae, and Cichlidae (3\%), Pristigasteridae (2\%). At site B3 a total of 37 species were recorded belonging to 8 order and 14 family. Cyprinidae were the most dominant with $(32 \%)$ followed by Bagridae (13\%), Schilbeidae (11\%), Channidae (8\%), Clupeidae, Muglidae and Ambassidae (5\%), Pristigasteridae, Nemacheilidae, Claridae, Sisoridae, Heteropneustidae, Pangasiidae, and Cichlidae (3\%) which are presented in Figure 2-5 and table $1 \& 2$.

Order Siluriformes which includes families Bagridae, Sisoridae, Siluridae, Claridae, Schilbeidae, Heteropneustidae, Pangasiidae belong to catfishes has recorded maximum 7 number of families which indicates the dominance of catfishes with 16 species Sperata seenghala, Mystus vittatus, Mystus tengra, Mystus cavasius, Sperataaor, Ompok bimaculatus, Ompok pabda, Clarius gariepinus, Gagata cenia, Gogangra viridescens, Ailia coila, Clupisoma garua, Eutropiichthys vacha, Neotropius atherinoides, Heteropneus tesfossilis and Pangasius pangasius. Order Cypriniformes include families Cyprinidae and Nemacheilidae has recorded 16 species Cirrhinus reba, Cyprinus carpio, Puntius sophore, Salmophasia bacaila, Amblypharyn godonmola, Cabdiomorar, Devario devario, Barilius barila, Barilius bendelisis, Osteobrama cotiacotia, Labeo angra, Rasbora daniconius, Catlacatla, Cirrhinus mrigala, Labeo bata, and Pethiacon chonius. Order Clupeiformes includes families 
Clupeidae and Pristigasteridae has recorded 3 species Gonialosa manmina, Gudusia chapra and Ilishamegaloptera. Order Mugiliformes include family Mugilidae has recorded 2 species Rhinomugil corsula and Sicamugil cascasia. Order Ophiocephaliformes includes family Channidae has recorded 3 species Channa punctatus, Channastriata and Channam arulius. Order Anabantiformes includes family Osphronemidae has recorded 1 species Tricchogasterfaciata. Order Perciformes includes family Ambassidae has recorded 2 species Chanda nama and Parambasis ranga. Order Cichliformes includes family Cichlidae has recorded 1 species Oreochromis niloticus which are presented in Figure 2-5 and table $1 \& 2$.

The abiotic factors such as current velocity, temperature and substrate can determine the distribution and abundance of individual species (Rahel \& Hubert 1991). Physicochemical parameters of water at the three sampling stations markedly differ, this seem to be caused by variation in amount and duration of rainfall. The relative abundance and diversities of its component functional groups fluctuate in predictable cycles with the alternating hydrological regimes of the river. Greatest diversity in Cypriniformes and siluriformes has been reported by Johal and Rawal (2005) in Western Himalayan Hill stream. Jha et al., (2004) studied the fish fauna of Mahananda reservoir, NearSiliguri Town and Identified 49 Species of Fish. Bharat et al., (2005) reported 21 species of fishes from Darjeeling uplands. The river Yamuna has faced extreme degradation of water quality and scarcity of fresh water (Babu et al., 2013), which caused silt loading river bed, algal choking, extermination of sensitive native fish species and invasion of exotic fishes. The altered flow regime, river habitats and physico-chemical parameters turned adverse to the sensitive native fishes including IMC and large catfishes. As a result, the vacant habitats have been occupied by hardy exotic fishes. Studies on other Asian rivers have also found the more or less similar patterns (De Silva et al., 2007). Seasonal differentiation evident in higher number of species and individuals caught during wet months of the study period, agree with results of Welcome (1985), for floodplain rivers. Relatively higher fish densities and species richness values in the middle and lower river reaches, were probably because being mainly forest flood plains, as explained by Leigh (1990), these reaches offer a wide habitat heterogeneity that leads to a large number of potential ecological niches of fish species.

It has been concluded from the above study that the fishes of River Yamuna totally depend upon the physico-chemical parameters. The need is to protect the existing indigenous fish stock species and prevent polluting the rivers by industrial and domestic sewage, beside this we have to control the non-point pollution sources for better management of rivers so the water may remain suitable for their living.

\section{Acknowledgments}

Authors are grateful to Dr. Amita Saxena Head \&Professors Fisheries Resource Management and Dr. R.N.Ram Professors Fisheries Resource Management, for providing guidance and facilities to purse the present study at College of Fisheries of G. B. Pant University of Agriculture and Technology, Pantnagar.

\section{References}

APHA, 2012. Standard methods for the examination of the water and waste water. 22th edition. American Public Health Association, Washington Aquaculture Engineering. p. 19.

Babita, S. and Rao, S.N., 2015. A study on 
seasonal fluctuations in physicochemical variables in spring fed Kosi River at Almora province from central Himalaya, India. International Journal of Current Microbiology and Applied Sciences, 4(4), pp.418-425.

Babu, C.R., Gosain, A.K. and Gopal, B., 2013. Restoration and Conservation of River Yamuna. Final Report: Submitted to the National Green Tribunal by Expert committee.

Badola, S.P. and Singh, H.R., 1981. Hydrobiology of the river Alaknanda of the Garhwal Himalaya [India]. Indian Journal of Ecology (India).

Barat, S., Jha, P., Lepcha, P.F., 2005. Bionomics and cultural prospects of Katli, NeolissocheilusHexagonolepis (McClelland) in Darjeeling district of West Bengal. In: Coldwater fisheries research anddevelopment in north-east region of India (Eds.: B. Tyagi Shyam Sunder and M. Mohan)

Chitmanat, C. and Traichaiyaporn, S., 2010. Spatial and temporal variations of physicalchemical water quality and some heavy metals in water, sediments and fish of the Mae Kuang River,Northern Thailand. International Journal of Agriculture and Biology, 12(6), pp.816-820.

Day FS. (1951) The fishes of India. William and Sons Ltd., London

De Silva, S.S., Abery, N.W. and Nguyen, T.T., 2007. Endemic freshwater finfish of Asia: distribution and conservation status. Diversity and Distributions, 13(2), pp.172-184.

Duran, M. and Suicmez, M., 2007. Utilization of both benthic macroinvertebrates and physicochemical parameters for evaluating water quality of the stream Cekerek(Tokat, Turkey). Journal of Environmental Biology, 28(2), pp.231236.

Gautam, S.K., Maharana, C., Sharma, D.,
Singh, A.K., Tripathi, J.K. and Singh, S.K., 2015. Evaluation of groundwater quality in the Chotanagpur plateau region of the Subarnarekha river basin, Jharkhand State, India. Sustainability of Water Quality and Ecology, 6, pp.5774.

Jayaram KC (2010) The fresh water fishes of India, Pakistan, Burma and Sri-Lanka. Handbook Zoological Survey of India, No.2. xii +475

Jha, P. and Barat, S., 2003. Hydrobiological study of lake Mirik in Darjeeling Himalayas. Journal of environmental biology, 24(3), pp.339-344.

Jha, P., Mandal, A., Barat, S., 2004. Mahananda Reservior, W.B.: Its Ichthyofauna, Fishery and SocioeconomicProfile of Fish Production. Fishing Chimes, 24 (6): 1417.

Johal, M.S., Rawal, Y. K., 2005.Key to the management of the western Himalayan Hill streams inrelation to fish species richness and diversity. Hydrobiologia. 532: 225-232.

Khanna, D.R. and Bhutiani, R., 2003. Limnological characteristic of the river Ganga at Haridwar (Uttaranchal). Uttar Pradesh Journal of Zoology, 23(3), pp.179-184.

Khanna, D.R., Ashraf, J., Chauhan, B. and Bhutiani, R., 2005. Physico-chemical Analysis of River Panvdhoi at Saharanpur (UP). Environment Conservation Journal, 6(2), pp.89-94.

Khanna, D.R., Bhutiani, R., Tyagi, B., Tyagi, P.K. and Ruhela, M., 2012. Assessment of water quality of River Ganges during Kumbh mela 2010. Env. Cons. J, 13(3), pp.165-169.

Khanna, D.R., Sarkar, P., Gautam, A. and Bhutiani, R., 2007. Fish scales as bioindicator of water quality of River Ganga. Environmental monitoring and assessment, 134(1-3), p.153. 
Leigh EG (1990) Community diversity and environmentalstability: a reexamination. Trends EcolEcol 5:340359

May J.T., Brown. L.R. (2002). Fish communities of the Sacramento River basin: implications for conservation of native fishes in the Central Valley, California. Environmental Biology of Fishes 63: 373-388.

Murphy, G.E. and Romanuk, T.N., 2014. A meta-analysis of declines in local species richness from human disturbances. Ecology and evolution, 4(1), pp.91-103.

Pramod, K., Pandey, A. and Chandra, U.H., 2014. Seasonal variation in physicochemical properties of Kali River in Pithoragarh District of Uttarakhand, India. Journal of environmental Research and Development, 8(3), pp.600-606.

Rahel, F.J. \& Hubert, W.A. 1991. Fish assemblages and habitat gradients in a rocky mountain-great stream: biotic zonation and additive patterns of community change. Transaction of the American Fisheries Society 120: 319332.

Singh, J.P., Singh, S. and Khanna, D.R., 2006. Water Quality Status of River Ganges In Respect ofPhysico Chemical and Microbial Characteristics atAnupshahar, District-Bulandhshar (India). Environment Conservation Journal, 7(1-2), pp.29-34.

Skjoldal, H.R., Wiebe, P.H. and Foote, K.G., 2000. Sampling and experimental design. In ICES zooplankton methodology manual (pp. 33-53). Academic Press.

Talwar PK, Jhingran AG. (1991) Inland fishes of India and adjacent countries. Vol 1 \& VII. Oxford \& IBH Publ. Co. Pvt. Ltd; New Delhi.

Welcomme RL (1985) River fisheries. Food and AgricultureOrganization, Technical Paper 262. Rome, Italy.

\section{How to cite this article:}

Sumit Kumar and Amita Saxena. 2021. Fish Composition at Three Different Sites in Relation to Physico-chemical Characteristic of Yamuna River, India. Int.J.Curr.Microbiol.App.Sci. 10(01): 2203-2216. doi: https://doi.org/10.20546/ijcmas.2021.1001.253 